\begin{tabular}{|c|c|c|c|}
\hline $\begin{array}{c}A \\
\text { REVIEW }\end{array}$ & $\begin{array}{r}\text { ADVANCE RESEARC } \\
\text { Volume } 8 \mid \text { Issue } 1 \mid\end{array}$ & $\begin{array}{l}\text { OCIAL SCIENCE } \\
231-6418\end{array}$ & \\
\hline $0=$ & DOI: 10.15740/HAS/ARJSS/8.1/107-110 & Visit us : www.researchjournal.co.in & \\
\hline
\end{tabular}

\title{
A review on applications of multimedia and e-education technology in smart education
}

Chanchal Rana and Sunita Mishra*

Department of Human Development and Family Studies, School of Home Science, Babasaheb Bhimrao Ambedkar University, LUCKNOW (U.P.) INDIA

(Email: chanchalrana.444@gmail.com; sunitabbau@gmail.com)

\section{ARTICLE INFO :}

Received : 23.03.2017

Accepted : 27.05 .2017

\section{KEY WORDS :}

Smart class, E-Education, Smart education, Multimedia

HOW TO CITE THIS ARTICLE :

Rana, Chanchal and Mishra, Sunita (2017). A review on applications of multimedia and e-education technology in smart education. Adv. Res. J. Soc. Sci., 8 (1) : 107-110, DOI: 10.15740/HAS/ ARJSS/8.1/107-110

*Author for correspondence

\section{ABSTRACT}

$21^{\text {st }}$ century declared to be the age of information and communication technology. Today's students have been raised in a world of instant access to knowledge and information, a word of automation, remote controls, and simulation capabilities to stimulate the mind. This paper is about the much growing technology "Multimedia and e-education". The usage of smart teaching techniques is now more prevalent in school as well as other colleges and institutes. It was generated back in 1980s and is growing since then. This new technology helps the students with the benefit of learning with a different experience. The methods of e-learning make the classroom more interactive and interesting. It has also created a greater impact on our society as well as on education system. E-textbook provides electronic textbooks which are actually used at learner's real class. Digital textbook uses the latest smart device and technology. 